\title{
Kernos
}

Revue internationale et pluridisciplinaire de religion grecque antique

9 | 1996

Varia

\section{Cult Clay Figurines in Ancient Thrace}

Archaeological Evidence for the Existence of Thracian Orphism

\section{Nikola Theodossiev}

\section{Q OpenEdition}

1 Journals

\section{Electronic version}

URL: http://journals.openedition.org/kernos/1169

DOI: 10.4000/kernos. 1169

ISSN: 2034-7871

\section{Publisher}

Centre international d'étude de la religion grecque antique

\section{Printed version}

Date of publication: 1 January 1996

ISSN: 0776-3824

\section{Electronic reference}

Nikola Theodossiev, «Cult Clay Figurines in Ancient Thrace », Kernos [Online], 9 | 1996, Online since 21 April 2011, connection on 01 May 2019. URL : http://journals.openedition.org/kernos/1169; DOI :

10.4000/kernos.1169 


\section{Cult Clay Figurines in Ancient Thrace:}

\section{Archaeological Evidence for the Existence of \\ Thracian Orphism}

Strange little clay objects and figurines have been discovered in some tumuli with rich Thracian aristocratic graves, excavated in Bulgaria during the first decades of 20th century. Archaeologists of that time defined the puzzling artefacts as magic things, maybe connected with healing rites, or simply as children's toys. The following scholars and many contemporary Bulgarian archaeologists also accept these attitudes. In the recent years, the number of clay figurines and objects grew up, being found not only in tumular graves, but also in flat cemeteries, sanctuaries and settlements ${ }^{1}$. The discovered artefacts are dated from the beginning of the Early Iron Age (11th-10th century BC) to the late Roman Period (end of the 2nd - beginning of the 3rd century after Christ) in Thrace. All of them are of extremely various shapes and it is very difficult to establish a general typology. An obvious common element is the quite primitive outlook of the figurines, which are handmade with no exception. At the same time, the different shapes of the artefacts are absolutely conservative without any development during the long period of their existence, so it is not possible to distinguish and date two figurines when they are out of clear archaeological context.

It is not easy to interpret the enigmatic finds and to understand their exact meaning. The main problem is that the ancient Thracians have been a nonliterate society, and all the information on their religion is indirect, given by Greek and Roman authors. However, the clear ritual situations, in which the main part of the clay artefacts are found, show that they are to be examined like cult attributes and symbols, connected with religious beliefs of the Thracian tribes. Their importance could be best seen in the aristocratic and king's graves, where the unattractive figurines have been rested together with many gold and silver art treasures.

In the recent decades some Bulgarian scholars started to examine the Greek Orphic and Pythagorean literary texts, revealing many common

1 Review on all the previous interpretations and the main finds in Thrace in N. THEODOSSIEV, The Sacred Play of the Orpbic, in Kultura, 2, 2 (1990), p. 64-78 (in Bulgarian); ID., The Mysterial Toys of the Thracian Orphics, in Orpbey, 2, 3-4 (1992), p. 92-100 (in Bulgarian). 
elements with the Thracian religion ${ }^{2}$. It was possible to formulate a theory about the so-called Thracian Orphism, which has been an aristocratic and esoteric doctrine. In this connection, one of the best archaeological proofs for the existence of Thracian mythological components, which were included during the syncretic formation of the Greek Orphism, can be seen on a silver appliqué from Letnitsa treasure (Fig.1), dated to the 4 th century $\mathrm{BC}^{3}$. The Thracian uranic-chthonic god appears there in the shape of a dragon, accordingly referred to as Zeus in the rationally treated Greek Orphic theogony. He is opposed by Dionysos Zagreus, the son of the god born of the hierogamy, who is holding the principal mysterial Orphic attribute -the mirror- which had mentioned from the 3rd century BC until the 4th century after Christ ${ }^{4}$. In Greek Orphic myths Zeus acquires the image of a dragon in order to engage in the sacred incest with Demeter or Persephone, while according to one of the variants of the myth, Zagreus "dismembered himself into everything" precisely when he was holding the mirror ${ }^{5}$. Here it must be specified also, that in many Thracian aristocratic male graves of the 5 th-4th century $\mathrm{BC}$, bronze mirrors were discovered together with gold and silver jewellery, weapons, clay cult figurines, etc. It is obvious, that these mirrors have not been rested like toilet articles in the rich men's burials, but like mystic attributes similar to the clay artefacts. On the other hand, in ancient Greek and Italian iconography there are few representations of Dionysos Zagreus from 4th century BC onwards, but always as a child $^{6}$. So, in that case it is not possible to seek a Greek influence on the Letnitsa appliqué, but on the contrary -the Titans on the Attic hydria of British Museum wear Thracian clothes.

Following the problems mentioned above, it is very interesting that descriptions of the so-called Orphic toys, preserved in some Greek and Roman literary texts, coincide with a part of the Thracian clay figurines and objects, and it seems that they are closely connected to each other. The earliest account of the Orphic toys, saved until today, can be seen in the Gurob papyrus of the 3rd century $\mathrm{BC}$, found in $\mathrm{Egypt}^{7}$. In the first column, lines $28-30$ of the papyrus, the

2 A. FOL, The Thracian Orpbism, Sofia, 1986 (in Bulgarian); ID., The Thracian Dionysos. Book One: Zagreus, Sofia, 1991 (in Bulgarian); D. POPOV, The God witb Many Names, Sofia, 1995 (in Bulgarian).

3 Already mentioned in N. THEODOSsiev, The Tbraclan Itbyphallic Altar from Poliantbos and the Sacred Marriage of the Gods, in OJA, 13, 3 (1994), p. 313-323.

4 O. KERN, Orphicorum fragmenta, Berolini, 1992, II 31, II 34, II 214.

5 On the dismemberment of Zagreus when holding mirror, see Ibid. II 209; on Zeus as a dragon: C. KERÉNYI, The Gods of the Greeks, London, $1976^{2}$, p. 252-254, with ancient literary sources, and especially NONNUS, Dion., VI, 155-165 (Keydell).

6 C. SMITH, Orpbic Mytbs on Attic Vases, in JHS, 11 (1890), p. 343-351; E. SIMON, Zagreus. Über orpbische Motive in Campanareliefs, in M. RENARD (ed.), Hommages à Albert Grenier, Bruxelles, 1962 (Coll. Latomus, 58), p. 1418-1427.

7 KERN, op. cit. (n. 4), II 31; on the cone as a symbol of the cosmos there is a later evidence of the 2nd century after Christ: Achilleus Tatios, Isag. ad Arati Pbenom., p. 77 (Vieborg). 
Orphic mysterial objects are mentioned: cone, rbombos, knucklebones and mirror, thrown in kalatbos. Of particular interest is the cone, which after Achilleus Tatios has been regarded as image of the cosmos probably by the Orphics and which is very usual among the Thracian cult objects, especially after the 5th century BC (Fig. 2d). Maybe the most remarkable are the clay cones covered with silver foil, found in an aristocratic tumular grave dated from the end of the 1st century after Christ, excavated near the village of Slatina, Lovech district. Simultaneously, it is well known that many Thracians have lived in Egypt during the Hellenistic period ${ }^{8}$. So, it is possible to assume that the anonymous author of Gurob papyrus has been occasionally affected by some Thracian sacred narratives and rites, performed in Egypt.

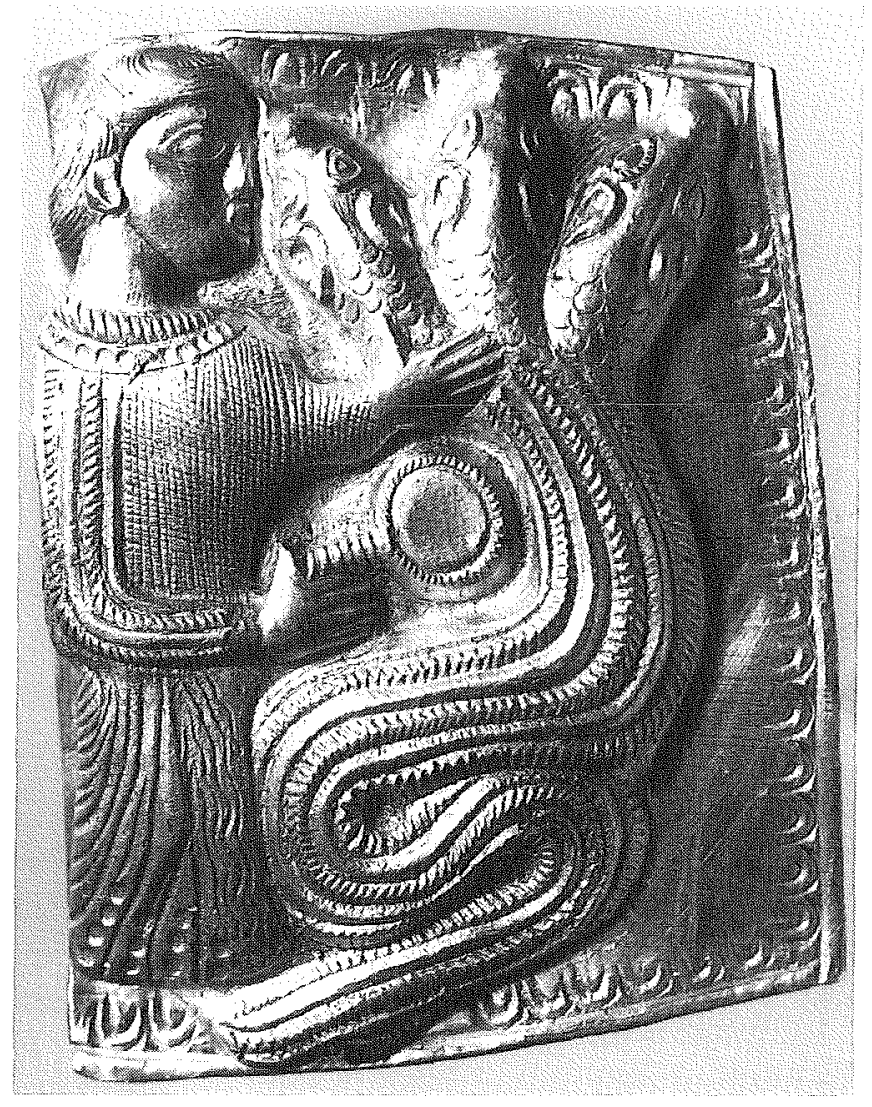

Fig. 1 : The Letnitsa appliquê, 4th century BC. 
The following most eloquent account on the Orphic toys is included in Protreptikos written by Clement of Alexandria9, an early Christian Father who lived in the second half of the 2 nd - first decade of the 3 rd century AD. After Clement, Orpheus the Thracian said: cone, rbombos, movable toys (figurines?) and the fruits of Hesperides. In the following lines the Father adds: knucklebone, sphere, whipping-top, apple, rbombos, mirror and fleece, all of them connected with the pagan mysteries. Although many informations of Clement's Protreptikos are not very reliable, it seems that the descriptions mentioned above follow an old Orphic literary tradition.
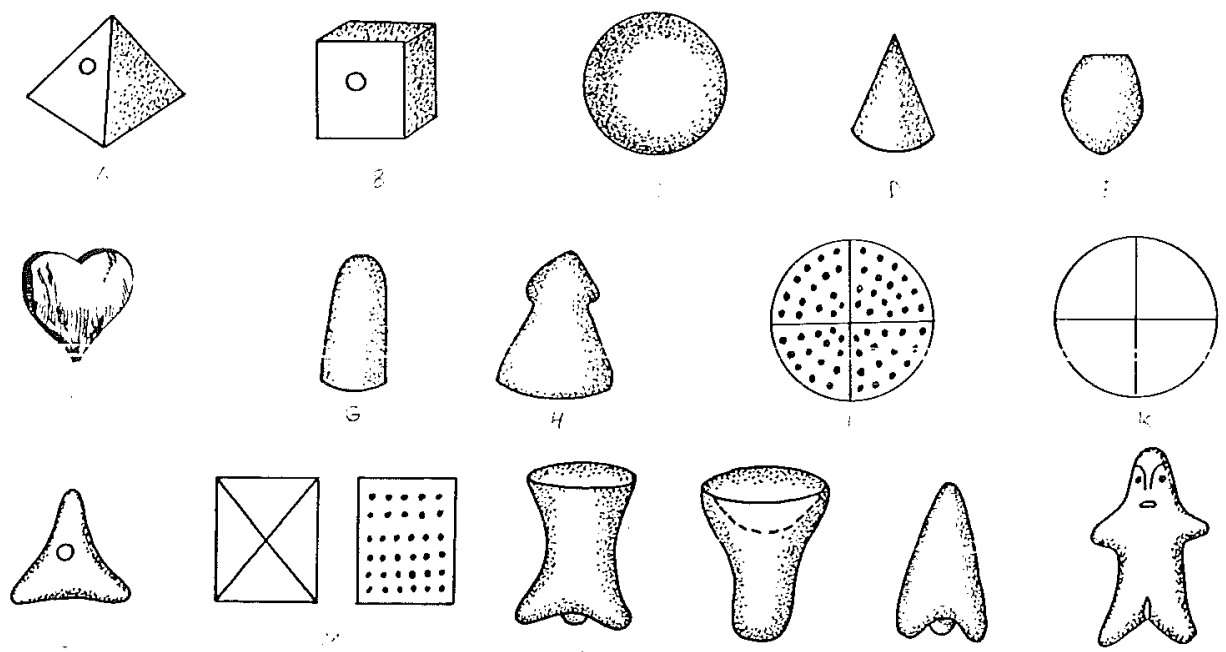

0

$\vec{x}$
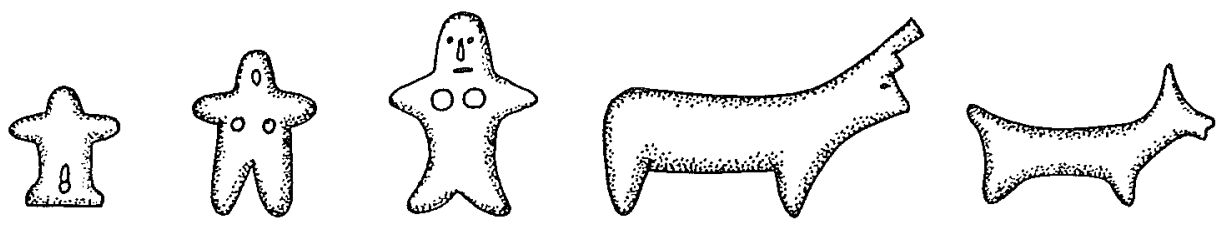

Fig. 2 : Different Thracian clay figurines and objects (without scales).

Among the sacred objects -some ones already known from Gurob papyrus-, very important are the movable toys, which maybe represented little

9 KERN, op. cit. (n. 4), II 34. 
figurines. Such figurines in ancient Thrace were the anthropomorphic and zoomorphic idols, the most widespread cult artefacts. The human figurines are always with very well represented sex (Fig. 2q, r, s, t), and it is possible to identify them with the images of the Great Goddess and the male god. The little clay animals -deers (Fig. 2u), bulls (Fig. 2v), rams, horses, he-goats, etc.are among the usual sacrificial victims in the Thracian burials and sanctuaries.

Of upmost interest is the sphere, which also is well attested among the Thracian objects (Fig. 2c). The sphere is mentioned in another early Christian apologetic literature as well, where it could be connected again with Orphic ideas $^{10}$. However, this object is most connected with the Pythagorean notions about the cosmogonic elements, because the sphere has been associated with the fire and the divine power ${ }^{11}$. Following Pythagorean ideas, the pyramid and the cube must be specified also. After Aëtius, Pythagoras said that the fire appears from the pyramid and the earth from the cube ${ }^{12}$. Obviously, these geometric figures have been perceived like the central cosmogonic beginnings. Again Clement of Alexandria mentioned the pyramid among the sacred symbols of the Eleusinian (or Orphic?) mysteries ${ }^{13}$. As one can already expect, many little pyramids (Fig. 2a) and cubes (Fig, 2b) are among the cult clay objects found in Thrace. All the statements above, together with another literary account by Epiphanius on some cult objects and symbols in Eleusis which are usual in the Orphic rites as well ${ }^{14}$, are very eloquent as to the common elements and links between Greek Orphism and Pythagoreanism ${ }^{15}$, and between Orphic and Eleusinian mysteries ${ }^{16}$.

The last evidence by Clement of Alexandria, which will be mentioned here, is about the death of Dionysos Zagreus. After the Father, when the god had been torn to pieces and partly eaten by the Titans, the goddess Athena picked up the divine heart and shook it out of the blood ${ }^{17}$. The important role of Zagreus' heart in the Orphic beliefs can be well seen in the later narrative by

\footnotetext{
10 Ibid., II 56, II 247, 25.

11 Cf. AËTIUS, De plac. phil., I, 7, 16 et II, 8, 2 (Diels); HIPPOL,, De Refutat. omn. baeres., I, 15, p. 18,6 (Wendland).

12 AËTIUS, De plac. pbil., II, 6, 5 (Diels); $c f$. also THEOPHR., De igne, 52 (Gercke) and SIMPLIC., In Arist. comment. de anima, p. 68, 5 (Berol).

13 Clem. Alex., Protrept., II, 6 (Migne).

14 KERN, op. cit. (n. 4), II 34.

15 W. BURKERT, Orphism and Baccbic Mysteries: New Evidence and old Problems of Interpretation, in The Center for Hermeneutical Studies in Hellenistic and Modern Culture, Colloquy, 28 (1977), p. 1-8; L.J. ALDERNIK, Creation and Salvation in Ancient Orphism, Ann Arbor, 1981, p. 7-23 with op. cit.; W. BURKERT, Craft versus Sect: the Problem of Orpbics and Pythagoreans, in B.H. MEYER, E.P. SANDERS (eds.), Jewish and Christian Self-Definttion, III: SelfDefinition in the Graeco-Roman World, London, 1982, p. 1-22.

16 Fr. GRAF, Eleusis und die orphiscbe Dicblung Atbens in vorbellenistiscber Zeit, Berlin - New York, 1974, passim; BURKERT, Orpbism and Baccbic... (n. 15); ALDERINK, op. cit. (n. 15).

17 KERN, op. cit. (n. 4), II 35.
} 
Iulius Firmicus Maternus, where it has been connected with the worship of the dead god ${ }^{18}$. It must be pointed out also, that in mythological tradition, Semele became pregnant with the second Dionysos, after she drunk a potion from the heart of Zagreus, given by Zeus ${ }^{19}$. In the context of above mentioned, most interesting is the unusual heart-like (or leaf-like?) shape of two gold leaves of the end of the 4th century $\mathrm{BC}$, found in Thessaly ${ }^{20}$. The two lamellae contain Bacchic-Orphic ritual texts. In ancient Thrace, a clay heart is discovered in the royal tholos tomb near the town of Strelcha, dated to the 4 th century BC (Fig. 2f). Most likely, this important human organ has been eaten during the Thracian sacrifices ${ }^{21}$ and this terrible practice has reflected the ritual tasting of Zagreus' body in the Greek Orphic myths.

Following the earlier apologetic literary tradition, the next description of Orphic toys is preserved in Arnobius' Adversus nationes of the 3rd-4th century after Christ $^{22}$. The attributes connected with dismemberment of Zagreus have been: knucklebones, mirror, whipping-tops (spindles?), rolling wheels (most probably iunges $^{23}$ ), balls (spheres?) and fruits of the Hesperides. Among these sacred objects, most attention here deserve the eventual spindles, which are extremely usual in Thracian burials and sanctuaries.
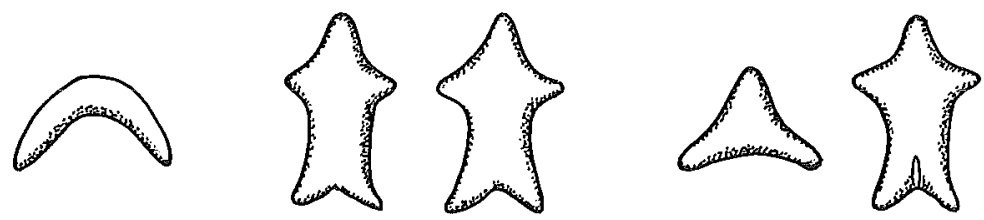

Fig. 3: The scene on Pomorie dish, 1st century after Christ

The last evidence, containing information on the Orphic toys, is given by Iulius Firmicus Maternus, a Roman writer of the 4th century after Christ. The author told a literary framed version of Zagreus' myths on Crete ${ }^{24}$, where the

18 Ibid., II 215.

19 KERÉNYI, op. cit. (n. 5), p. 257 with ancient evidence.

20 K. TSantsanogloU, G.M. Parassoglou, Two Gold Lamellae from Thessaly, in Hellenika, 38 (1987), p. 3-16.

21 On the human sacrifices in Thrace, see POPOV, op. cit. (n. 2), p. 59-106; N. THEODOSSIEv, The Sacred Motuntain of the Ancient Tracians, in Tbracia, 11 (1995), p. 371-384 (= Studia in bonorem Alexandri $F o l$ ).

22 KERN, op. cit. (n. 4), II 34.

23 On the already mentioned Orphic rhombos, iunx and other music instruments connected with different rites, see A. GOW, Itnx; Rbombos, Rhombus, Turbo, in JHS, 54 (1934), p. 1-13.

24 KERN, op. cit. (n, 4) II 214. 
young god was captured by the Titans through the mirror and rattles. There are several Thracian egg-like clay rattles again, dated to the 5th-4th century BC and consisting of hollow bodies with little pellets in them (Fig. 2e). They obviously had the important role of rhytming of the rites. The shape of these rattles, together with many other clay eggs found in Thracian graves, is of special interest here. It is well know, that in the Greek Orphic cosmogony the main power for the creation of the world is Eros (Phanes, Protogonos, Erikepaios), who has been born from the cosmic egg -a clear symbol of the cosmos in the Orphic and Bacchic mysteries ${ }^{25}$. In ancient Thrace the egg most probably had a similar symbolism, connected with the birth of the god. Very eloquent for this interpretation is a late Hellenistic tumulus without human grave, excavated near the village of Radovene, Vratsa district. Only an egg-like hollow, plastered with red clay, and a sacrificed dog, rested in this quite primitive little chamber, were discovered in the tumular embankment. Perhaps, in this case the sacred dog, lain in the red egg, has been perceived like a zoomorphic incarnation of the supreme Thracian male god with phallic power ${ }^{26}$.

Among the clay artefacts from Thrace there are many phallic cones (Fig. $2 \mathrm{~h}$ ) and phalloi (Fig. 2g) again connected with the male god, little discs (Fig. 2i, k) -the aniconic images of the solar god ${ }^{27}$, altars (Fig. 2n), cauldrons (Fig. 2o), conic tripodes (Fig. 2p.), etc. Some of them could be connected with the Orphic myths, but they are not attested among the Orphic toys and will be not studied here.

Very rare is a little clay dish with plastic images on the inner walls, found in a rich tumular grave of the 1st century after Christ, near the town of Pomorie. On the bottom there is a snake, very clear chthonic personage, and an ompbalos, which has been accepted like a sacred centre of the world in Delphi and elsewhere ${ }^{28}$. A ritual scene is depicted on the walls: phallic male figurine with triangle-like object, standing near to two female figurines and crescent (Fig. 3). In accordance with Pythagorean notions, the triangle has been connected with the male gods, and quadrangle with female goddesses ${ }^{29}$. There are many other triangle-like (Fig. 21) and tetragon-like (Fig. 2m) clay Thracian mysterial objects, which could lead to similar conclusions. Logically, the clay moon is close to the female figurines. The goddess Selene had a role in the Orphic theogony and

25 W.K.C. GUTHRIE, Orpheus and Greek Religion, London, 1935, passim; A. ANEMOYANNISSINANIDIS, Le symbolisme de l'ceuf dans les cosmogonies orphiques, in Kernos, 4 (1991), p. 83-90; on the egg like a symbol of the cosmos especially see: ACHILLEUS TATIOS, Isag. ad Arati Phenom., p. 77 (Vieborg) and MACROB., Sat., VII, 16, 691 (Willis).

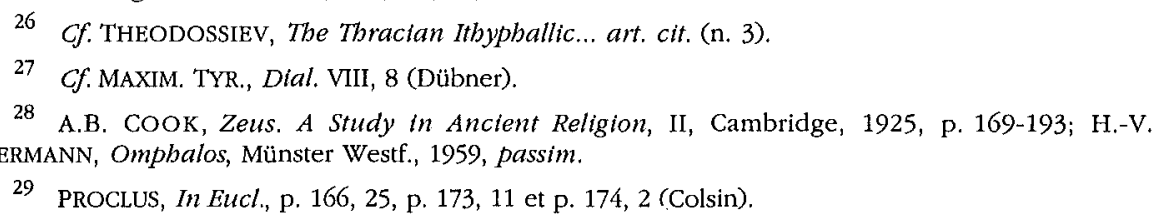


myths ${ }^{30}$, sometimes associated with Bendis or Hecate ${ }^{31}$. Very significant here is the clay "pregnant" crescent, found in the Thracian sanctuary of the 7th-4th century BC, near the village of Debelt, Burgas district. It is clear, that in ancient Thrace the moon could be accepted like the aniconic image of the Great Goddess.

After some literary versions on the death of Dionysos Zagreus, he has been decoied through the Orphic toys and then dismembered by the Titans ${ }^{32}$. Similar was the fate of Orpheus, who has been torn to pieces by women ${ }^{33}$. Obviously, dismemberment of the divine body was a typical Orphic rite, maybe connected with resurrection of the god. In the usual Greek Orphic ritual practice the human victim undoubtedly has been replaced by some zoomorphic incarnation of the god. However, in some Tracian tumuli from the beginning of the Early Iron Age down to the late Hellenistic period, the bodies of the dead aristocrats and kings have been dismembered ${ }^{34}$. This Thracian Orphic rite could be easily explained: the deceased nobleman has been identified with the dying god. Most probably, the play of Zagreus with the sacred objects just before his death, had some eschatological and cosmogonical meaning. Similarly, the Thracian cult figurines, many of them being cosmogonical symbols, may have been used by participants in the different rites to structure the cosmos.

It is not surprising that the main part of descriptions of the Orphic mysterial toys are preserved in the early Christian apologetic literature. The Fathers had a clear task: to reveal well and to stigmatize the sacraments of the pagan mysteries. I hope that the principal idea in this short article is clear: there have been common elements between the Thracian ritual practice from one side, and the Greek Orphic myths and Pythagorean ideas from another. It is possible to suppose, that the ancient Greeks have borrowed some notions, myths and rites from Thrace, during the syncretic formation of the Orphism and the Pythagoreanism.

Sofia University "St. Kliment Ohridski"

Nikola Theodossiev

Department of Archaeology

15 Tsar Osvoboditel Boul.

1000 SOFIA

Bulgaria

30 KERN, op. cit. (n. 4), I 167, II 3, II 272, II 283, II 280, 8, II 286, II 288 a.c., II 300, 2.

31 Ibid., II 200, II 204.

32 Ibid., II 34, II 214.

33 Ibid., I, 113-135.

34 D. GERGOVA, Thracian Burial Rites of the Late Bronze and Early Iron Age, in J. BEST, N. DE VRIES (eds.), Thracians and Mycenaeans, Leiden - Sofia, 1989, p. 231-240; N. THEODOSSIEV, Thracian Tumulus near the Town of Kavarna, in Helis, 3, 1 (1994), p. 109-122 with op. cit.; K. KISYOV, The Rite diasparasso (anatemno) in the Burlal Practice of the Thraclan Tribes in Rhodope Mountains during the Second Half of the 2nd - 1st Millenium BC, in Annual of the Archaeological Department at the New Bulgarian University, 1 (1994), p. 174-177 with op. cit. (in Bulgarian). 